\title{
Update of mercury emissions from China's primary zinc, lead and copper smelters, 2000-2010
}

\author{
Q. R. Wu, S. X. Wang, L. Zhang, J. X. Song, H. Yang, and Y. Meng \\ School of Environment, and State Key Joint Laboratory of Environment Simulation and Pollution Control, \\ Tsinghua University, Beijing 100084, China
}

Correspondence to: S. X. Wang (shxwang@tsinghua.edu.cn)

Received: 30 May 2012 - Published in Atmos. Chem. Phys. Discuss.: 24 July 2012

Revised: 13 October 2012 - Accepted: 5 November 2012 - Published: 26 November 2012

\begin{abstract}
China is the largest anthropogenic mercury emitter in the world, where primary nonferrous metal smelting is regarded as one of the most significant emission sources. In this study, atmospheric mercury emissions from primary zinc, lead and copper smelters in China between 2000-2010 were estimated using a technology-based methodology with comprehensive consideration of mercury concentration in concentrates, smelting processes, mercury removal efficiencies of air pollution control devices (APCDs) and the application percentage of a certain type of APCD combinations. Our study indicated that atmospheric mercury emissions from nonferrous metal smelters in 2000, 2003, 2005, 2007 and 2010 were $67.6,100.1,86.7,80.6$ and $72.5 \mathrm{t}$, respectively. In 2010 , the amounts of mercury emitted into atmosphere were $39.4 \pm 31.5,30.6 \pm 29.1$, and $2.5 \pm 1.1 \mathrm{t}$ from primary zinc, lead and copper smelters, respectively. The largest amount of mercury was emitted from the Gansu province, followed by Henan, Yunnan, Hunan, Inner Mongolia and Shaanxi provinces. $\mathrm{Hg}^{2+}, \mathrm{Hg}^{0}$ and $\mathrm{Hg}^{\mathrm{p}}$ emissions from zinc smelters were $25.6,11.8$ and $1.97 \mathrm{t}$, respectively. The emissions percentages of $\mathrm{Hg}^{2+}$ and $\mathrm{Hg}^{0}$ were almost the same from lead and copper smelters. The average mercury removal efficiency was $90.5 \pm 52.5 \%, 71.2 \pm 63.7 \%$ and $91.8 \pm 40.7 \%$ in zinc, lead, and copper smelters, respectively.
\end{abstract}

\section{Introduction}

Studies on atmospheric mercury emissions from major sources have been intensively carried out in the past several years due to the worldwide concern about mercury contamination (Strode et al., 2009; Li et al., 2009, 2010; Lin et al.,
2010; Wu et al., 2010; Tian et al., 2010, Kocman and Pacyna, 2011; Fukuda et al., 2011). Nonferrous metal smelting is believed to be one of the most significant anthropogenic mercury emission sources. Global atmospheric mercury emissions from nonferrous metal smelters in 2007 reached $310 \mathrm{t}$, of which about $203 \mathrm{t}$ were emitted from China. Atmospheric mercury emission from Chinese nonferrous metal smelters was estimated to be $9 \%$ of the total global anthropogenic emissions (Streets et al., 2005; Wu et al., 2006; Hylander and Herbert, 2008; Pirrone et al., 2010; Wang et al., 2010).

The main factors affecting atmospheric mercury emissions from nonferrous metal smelters include the mercury concentration in ore concentrate, smelting technology, the type of APCD combination applied and the application percentage of a certain type of APCD combinations. Current inventories reflecting atmospheric mercury emissions from China's zinc, lead and copper smelters are subject to high uncertainty due to the following reasons: first, the range of mercury content of global ore concentrates was reported too vague and there are few data about mercury concentration in Chinese concentrates. Global results concerning mercury content in concentrates from Brook Hunt and Associates Ltd. indicated that the maximum concentrations are 6000,325 and $1500 \mathrm{~g} \mathrm{t}^{-1}$ for zinc, lead and copper concentrates, respectively, while the minima are all less than $1 \mathrm{~g} \mathrm{t}^{-1}$ (Hylander and Herbert, 2008). However, no data about China's mines were noted in this report. Streets et al. (2005) reported that mercury concentration in Chinese zinc concentrates varied from less than $1 \mathrm{~g} \mathrm{t}^{-1}$ to more than $1000 \mathrm{~g} \mathrm{t}^{-1}$. Yin et al. (2012) pointed out that such a wide range depended on the ore types and their geneses. Data about mercury concentration in Chinese lead and copper concentrates are scarce. 
Secondly, in most previous studies, an average emission factor was used to estimate emissions, which did not consider the removal effect of APCDs. Hylander and Herbert (2008) pointed out the synergic effect of APCDs, but the mercury removal efficiencies in their paper were estimated on the basis of sulfur abatement technology. About $95 \%$ of gaseous mercury was removed from flue gas in zinc/lead smelters with sulfuric acid plants, and no mercury removal tower (Hylander and Herbert, 2008). However, such kind of assumption neglected the different removal efficiencies of various types of sulfuric acid plant. Field measurements conducted in China's zinc, lead and copper smelters indicated the total mercury removal efficiency for zinc/lead smelters with double-contact sulfuric acid plants and no mercury removal tower is over $99 \%$ while mercury removal efficiency is only $89 \%$ for $\mathrm{Zn} / \mathrm{Pb}$ smelters with single-contact sulfuric acid plants (Li et al., 2010; Wang et al., 2010; Zhang et al., 2012). In this study, these updated removal efficiencies of APCDs will be used for emission estimation.

Thirdly, various smelting processes and APCDs are used in China's smelters and they have been improved in the past decade because of the stringent regulations for environmental protection. Therefore, the emission factors used in previous studies will not apply to the current situation since the application percentage of the types of APCD combinations in smelters has been undergoing change. Streets et al. (2005) adopted the average mercury emission factors of 86.6, 43.6 and $9.6 \mathrm{~g} \mathrm{t}^{-1}$ for zinc, lead and copper, respectively, mainly based on the average mercury concentration in concentrates without consideration of APCDs. Hylander and Herbert (2008) estimated the emission factors of 16.61, 14.91 and $6.72 \mathrm{~g} \mathrm{t}^{-1}$ for zinc, lead and copper smelters, respectively, in the global inventory of 2005 for China's nonferrous metal smelters. However, the increased application percentage of acid plants after 2005 indicates that these emission factors are not presently applicable to China.

In this paper, nationwide as well as imported concentrates have been sampled and analyzed for mercury content. Upto-date mercury removal efficiencies in the existing literature have been summarized and applied. Moreover, information on smelting technologies as well as APCDs has been investigated throughout China. A technology-based method with comprehensive consideration of the above factors is used to estimate atmospheric mercury emissions from primary zinc, lead and copper smelters in China between 2000-2010.

\section{Methodology}

Various smelting processes are used in China's nonferrous metal smelters. Zinc smelting processes include oxygen pressure leaching process (OPLP), electrolytic process (EP), imperial smelting process (ISP), retort zinc smelting process (RZSP), electric zinc furnace (EZF), and artisanal zinc smelting process (AZSP). There is no atmospheric mer- cury emission from OPLP since it is a hydrometallurgical process and mercury in ore concentrates is released into water or solid waste. Lead smelting processes can be divided into four major types: rich-oxygen pool smelting process (RPSP), imperial sinter process (ISP), sinter machine process (SMP), and sinter pan or pot process (SPP). Copper smelting processes include flash furnace smelting process (FFSP), rich-oxygen pool smelting process (RPSP), imperial furnace smelting process (IFSP), roasting-leachingelectrolyzing process (RLEP) as well as the outdated technologies that were forbidden by the Chinese government such as electric furnace smelting process (EF) and the revelatory furnace smelting process (RF).

In all the above processes, although additives such as quartz stone and limestone also contain limited mercury, ore concentrate is the main source of mercury input. Mercury input $Q$ for smelters with $j$ technology in $i$ province can be calculated using the following equations.

$Q_{i j}=[\mathrm{Hg}]_{\mathrm{com}, i j} C_{\mathrm{com}, i j}$

$[\mathrm{Hg}]_{\mathrm{com}, i j}=\frac{\sum_{k}[\mathrm{Hg}]_{\mathrm{su}, k \rightarrow i j} C_{\mathrm{su}, k \rightarrow i j}}{\sum_{k} C_{\mathrm{su}, k \rightarrow i j}}$

$C_{\mathrm{com}, i j}=\sum_{k} C_{\mathrm{su}, k \rightarrow i j}$

where $[\mathrm{Hg}]_{\mathrm{com}, i j}$ and $C_{\mathrm{com}, i j}$ are mercury content and amount of the ore concentrates consumed by $j$ technology in $i$ province. $[\mathrm{Hg}]_{\mathrm{com}, i j}$ is calculated based on mercury content in the concentrates supplied by $k$ province and concentrates trade between provinces (see Eq. 2). In Eq. (2), $[\mathrm{Hg}]_{\mathrm{su}, k \rightarrow i j}$ and $C_{\mathrm{su}, k \rightarrow i j}$ are mercury content and supply of ore concentrates produced in $k$ province that are transported to $j$ technology in $i$ province for smelting. The value of $[\mathrm{Hg}]_{\mathrm{su}, k \rightarrow i j}$ is from our own survey results. The survey was conducted in China's main ore mineral and smelting plants. The number of sampling mines (see Table S1), and sampling, preparation and analysis methods are described in the supplementary material. Geometric mean of all mines was used to represent national mercury content since the distribution of mercury content meets the skewed distribution (see Table 1 and Fig. S1). Most concentrates have low mercury content, typically less than $10 \mathrm{~g}$ mercury t $\mathrm{t}^{-1}$ copper concentrates, or $20 \mathrm{~g}$ mercury $\mathrm{t}^{-1}$ zinc/lead concentrates (see Table 1 and Fig. S1). The transportation data $C_{\mathrm{su}, k \rightarrow i j}$ between provinces were based on the trade between ore mineral plants and 244 smelters in our investigation (see Tables S2, S3, S4). The value of $[\mathrm{Hg}]_{\mathrm{com}, i j}$ is listed in Table 1, and Fig. $1 . C_{\mathrm{com}, i j}$ is calculated according to Eq. (3). The value of $C_{\mathrm{com}, i j}$ is shown in Tables S2, S3, and S4.

Based on the mercury content and amount of concentrates consumed in each province, the weighted national average of mercury content of zinc, lead and copper concentrates consumed by China's smelters in 2010 was $40.27,20.03$ and 


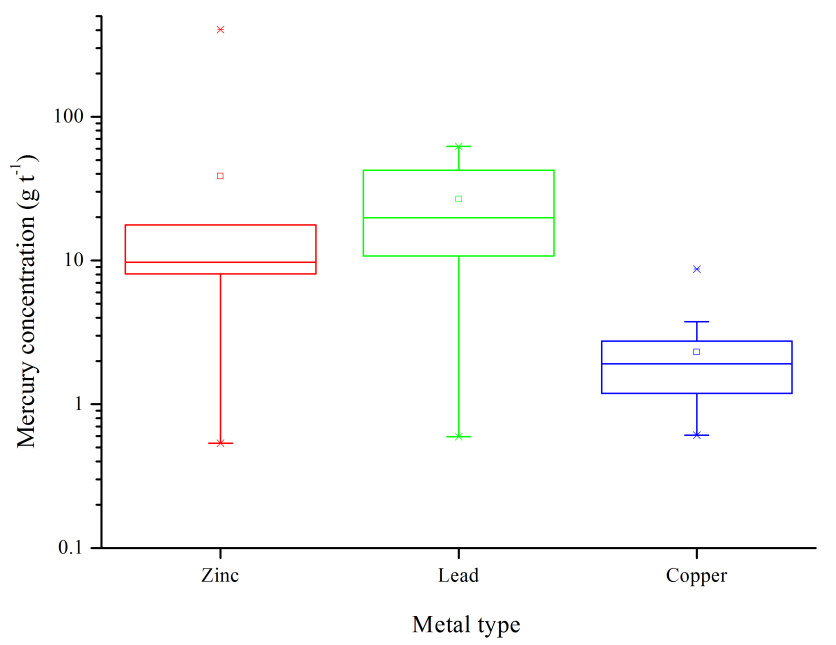

Fig. 1. Mercury concentration in concentrates consumed by smelters.

$2.25 \mathrm{~g} \mathrm{t}^{-1}$, respectively, according to Eq. (4), while the corresponding results are $47.02,16.81$ and $2.82 \mathrm{~g} \mathrm{t}^{-1}$, respectively, in 2005 .

$[\mathrm{Hg}]=\frac{\sum_{i} \sum_{j}[\mathrm{Hg}]_{\mathrm{com}, i j} C_{\mathrm{com}, i j}}{\sum_{i} \sum_{j} C_{\mathrm{com}, i j}}$

Mercury in ore concentrates is released in the form of gaseous mercury during pyrometallurgical extraction processing , and a portion is captured by APCDs and transferred to waste water, acid or fly ash. Usually, pyrometallurgical extraction of nonferrous metals from concentrate requires dehydration, smelting/roasting, extraction and reclaiming/refining (Fig. 2). Total atmospheric mercury emissions from one smelter include the sum of emissions from the above four procedures. Mercury emission from smelting flue gas, excluding overflow flue gas, is termed as the primary flue gas emission $\left(E_{\mathrm{p}}\right)$. Mercury emission from dehydration, overflow, extraction and refining/reclaiming flue gas is regarded as other emissions $\left(E_{0}\right)$. The atmospheric mercury emissions for smelters with $j$ technology in $i$ province can be calculated with the following equation.

$E_{i j}=E_{\mathrm{p}, i j}+E_{\mathrm{o}, i j}$

The mercury removal effect of APCDs has been proved in previous studies (Wang et al., 2010; Li et al., 2010; Zhang et al., 2012). Generally, APCDs for primary flue gas in most nonferrous metal smelters consist of dust collectors (DC) including cyclone dust collector, waste heat boiler, electrostatic precipitator and fabric filter (or their combination), flue gas scrubber (FGS), electrostatic demister (ESD), mercury reclaiming tower (MRT), and conversion and absorption tower (CAT). The CAT may be a double conversion double absorption (DCDA) tower or a single conversion single absorption (SCSA) tower. Usually, the above APCDs combined into 7

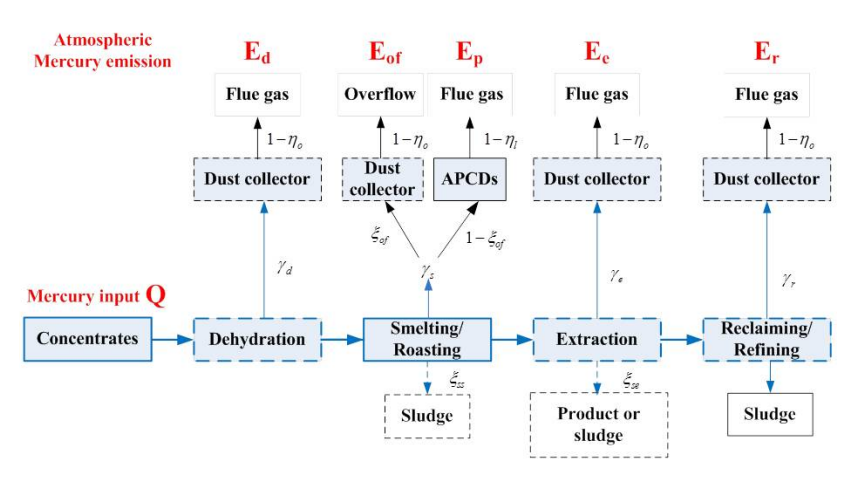

Fig. 2. Flow diagram for nonferrous metal smelters.

types used in smelters (Table 2). The information about the type APCD combinations in most smelters is based on our investigation of 244 nonferrous metal smelters. For smelters without APCD combination information but with acid making, we assumed that the type 1 of APCD combinations $(\mathrm{DC}+\mathrm{FGS}+\mathrm{ESD}+\mathrm{DCDA})$ was adapted. For smelters without any information about acid production or APCDs, type 7 (none APCDs) was adapted. The proportion of metal production from smelters with different types of APCDs is given in Table 2. Combining the effect of APCDs and the mercury flow diagram in smelters (Fig. 2), atmospheric mercury emission from primary flue gas is calculated with the following equation.

$E_{\mathrm{p}, i j}=\sum_{1} \theta_{\mathrm{l}, i j} Q_{i j}\left(1-\gamma_{\mathrm{d}, j}\right) \gamma_{\mathrm{s}, j}\left(1-\xi_{\mathrm{of}, j}\right)\left(1-\eta_{1}\right)$

where $E$ is atmospheric $\mathrm{Hg}$ emission $(\mathrm{kg}) ; p$ refers to primary smelting flue gas; $i$ refers to province; $j$ refers to technology. $\theta$ is the application percentage of a certain type of APCD combinations; information about $\theta$ is obtained from our investigation of 244 smelters and China's Nonferrous Metal Industry Association (Table S3). "l" is the type of APCD combinations (Table 2). $Q$ is mercury input (kg). $\gamma$ is the mercury release rate; the value of $\gamma$ was based on our field experiments in Chinese smelters ( $\mathrm{Li}$ et al., 2007; Wang et al., 2010; Zhang et al., 2012). For technology without field experiment, the median value of the results from other technologies was applied. Mercury release rates in various smelting process, $\gamma_{\mathrm{s}}$, are in the range of $97.7-99.4 \%$ (Table S6). "d" refers to dehydration sector; "of" refers to overflow flue gas. $\xi$ is called as distribution coefficient (Table S6). $\xi_{\text {of }}$ refers to the proportion of gaseous mercury emitted into atmosphere as overflow flue gas. The value of distribution coefficient was calculated from the mercury mass balance of field experiment result (Li et al., 2007; Wang et al., 2010; Zhang et al., 2012). Mercury distribution rate for dehydration is $0.1-1.0 \%$ (Table S6). $\eta$ is mercury removal efficiency of APCD, the value of which was based on field experiment (Li et al., 2007; Wang et al., 2010; Zhang et al., 2012). The value of $\eta$ is shown in Table 3. 
Table 1. Mercury content in ore concentrates supplied and consumed by province in 2010.

\begin{tabular}{|c|c|c|c|c|c|c|}
\hline \multirow[t]{2}{*}{ Province } & \multicolumn{3}{|c|}{$\begin{array}{l}\text { Mercury content in ore concentrates } \\
\text { supplied by } k \text { province }[\mathrm{Hg}]_{\mathrm{su}, k \rightarrow i j},\left(\mathrm{~g} \mathrm{t}^{-1}\right)\end{array}$} & \multicolumn{3}{|c|}{$\begin{array}{c}\text { Mercury content in ore concentrates } \\
\text { consumed by } i \text { province }[\mathrm{Hg}]_{\mathrm{com}, i j},\left(\mathrm{~g} \mathrm{t}^{-1}\right)\end{array}$} \\
\hline & Zinc & Lead & Copper & Zinc & Lead & Copper \\
\hline Anhui & 4.10 & 14.66 & 0.34 & 4.10 & 5.13 & 13.03 \\
\hline Chongqing & & 114.91 & & & & \\
\hline Fujian & 0.54 & 12.63 & & 0.54 & & \\
\hline Gansu & 499.91 & 10.77 & 2.86 & 403.39 & 10.77 & 5.06 \\
\hline Guangdong & 72.16 & 43.75 & 0.05 & 33.15 & 39.91 & \\
\hline Guangxi & 9.34 & 10.13 & 0.62 & 10.43 & 6.92 & 25.56 \\
\hline Guizhou & & 25.67 & & 9.74 & & \\
\hline Hebei & 4.96 & 2.25 & & & & 9.11 \\
\hline Henan & & 6.86 & 0.99 & 16.06 & 19.78 & 10.22 \\
\hline Hubei & 4.72 & 1.31 & & & & 16.91 \\
\hline Hunan & 2.16 & 62.21 & 1.84 & 8.98 & 14.33 & 2.20 \\
\hline Inner Mongolia & 13.29 & 18.61 & 0.06 & 12.09 & 62.21 & 22.18 \\
\hline Jiangxi & 1.47 & 19.51 & 4.66 & 1.47 & 22.06 & 9.81 \\
\hline Jilin & & 55.58 & & & & 55.58 \\
\hline Liaoning & & 61.04 & & 8.07 & 42.47 & 37.85 \\
\hline Ningxia & & 0.6 & 1.77 & & 62.21 & \\
\hline Qinghai & 240.77 & 45.14 & & 8.44 & 0.60 & \\
\hline Shaanxi & & 4.92 & 1.5 & 73.61 & 45.26 & 45.14 \\
\hline Shandong & & & & & & 3.16 \\
\hline Shanxi & & 52.17 & 0.14 & 9.04 & & 24.06 \\
\hline Sichuan & 45.55 & 26.46 & 2.15 & 58.35 & & 26.46 \\
\hline Xinjiang & 16.86 & & 2.02 & 16.86 & & \\
\hline Tibet & 0.23 & 0.02 & & & & 10.29 \\
\hline Yunnan & 10.98 & 21.54 & 13.68 & 17.66 & 15.21 & 14.38 \\
\hline Zhejiang & 0.88 & 20.96 & & 0.88 & & 9.26 \\
\hline National & 9.74 & 10.29 & 2.87 & 40.27 & 20.03 & 2.25 \\
\hline Other countries & 9.04 & 3.16 & 0.88 & & & \\
\hline
\end{tabular}

Table 2. The proportion of metal production from smelters with different types of APCDs.

\begin{tabular}{|c|c|c|c|c|c|c|c|}
\hline \multirow[t]{2}{*}{ APCDs } & \multirow{2}{*}{$\begin{array}{l}\text { Type of APCDs } \\
\text { combination }(l)\end{array}$} & \multicolumn{2}{|c|}{ Zinc } & \multicolumn{2}{|c|}{ Lead } & \multicolumn{2}{|c|}{ Copper } \\
\hline & & Production (kt) & Percentage $(\%)$ & Production (kt) & Percentage $(\%)$ & Production (kt) & Percentage (\%) \\
\hline $\mathrm{DC}+\mathrm{FGS}+\mathrm{ESD}+\mathrm{DCDA}$ & 1 & 3841.05 & 76.31 & 1720.57 & 61.58 & 2721.28 & 93.15 \\
\hline $\mathrm{DC}+\mathrm{FGS}+\mathrm{ESD}+\mathrm{MRT}+\mathrm{DCDA}$ & 2 & 508.04 & 10.09 & 0.00 & 0.00 & 0.00 & 0.00 \\
\hline $\mathrm{DC}+\mathrm{FGS}+\mathrm{ESD}+\mathrm{SCSA}$ & 3 & 69.52 & 1.38 & 108.35 & 3.88 & 81.40 & 2.79 \\
\hline $\mathrm{DC}+\mathrm{FGS}$ & 4 & 37.24 & 0.74 & 179.67 & 6.43 & 18.09 & 0.62 \\
\hline $\mathrm{DC}$ & 5 & 172.07 & 3.42 & 37.52 & 1.34 & 2.44 & 0.08 \\
\hline FGS & 6 & 1.68 & 0.03 & 3.16 & 0.11 & 0.00 & 0.00 \\
\hline None* & 7 & 275.10 & 5.47 & 744.68 & 26.65 & 98.12 & 3.36 \\
\hline
\end{tabular}

* Smelters without detailed APCD information are treated as having no APCDs.

Atmospheric mercury emissions from other flue gas are calculated with the following equation.

$$
\begin{aligned}
& E_{\mathrm{o}, i j}=E_{\mathrm{d}, i j}+E_{\mathrm{of}, i j}+E_{\mathrm{e}, i j}+E_{\mathrm{r}, i j} \\
& \quad=Q_{i j} \gamma_{\mathrm{d}, j}\left(1-\eta_{\mathrm{o}, j}\right) \\
& \quad+Q_{i j}\left(1-\gamma_{\mathrm{d}, j}\right) \gamma_{\mathrm{s}, j} \xi_{\mathrm{of}, j}\left(1-\eta_{\mathrm{o}, j}\right) \\
& \quad+Q_{i j}\left(1-\gamma_{\mathrm{d}, j}\right)\left(1-\gamma_{\mathrm{s}, j}-\xi_{\mathrm{ss}, j}\right) \gamma_{\mathrm{e}, j}\left(1-\eta_{\mathrm{o}, j}\right) \\
& \quad+Q_{i j}\left(1-\gamma_{\mathrm{d}, j}\right)\left(1-\gamma_{\mathrm{s}, j}-\xi_{\mathrm{ss}, j}\right)\left(1-\gamma_{\mathrm{e}, j}\right. \\
& \left.\quad-\xi_{\mathrm{se}, j}\right) \gamma_{\mathrm{r}, j}\left(1-\eta_{\mathrm{o}, j}\right)
\end{aligned}
$$

where "o" refers to other flue gas; "d", "s", "e", and "r" refer to dehydration, smelting/roasting, extraction and refining/reclaiming, respectively. $\xi_{\text {ss }}$ and $\xi_{\text {se }}$ here refer to the proportion of mercury entering into the solid waste in the smelting and extraction sector, respectively. The values of $\xi_{\mathrm{ss}}$ and $\xi_{\mathrm{se}}$ are $0.02-20.6 \%$, and $2.4-14.4 \%$, respectively (Table S6). $\gamma_{\mathrm{d}}, \gamma_{\mathrm{e}}$, and $\gamma_{\mathrm{r}}$ are mercury release rate in hydration, extraction and refining/reclaiming process. The value of these three parameters is shown in Table S6. $\eta_{\mathrm{o}}$ is the mercury removal efficiency for other flue gases (Table S6). For 
Table 3. Mercury removal efficiency of APCD.

\begin{tabular}{|c|c|c|c|c|c|c|c|c|c|c|}
\hline \multirow{2}{*}{$\mathrm{APCD}$} & \multicolumn{6}{|c|}{ Zhang et al., $2012 \eta(\%)$} & \multirow{2}{*}{$\begin{array}{l}\text { Wang et al., } \\
\qquad \begin{array}{l}2010 \\
\eta(\%)\end{array}\end{array}$} & \multirow{2}{*}{$\begin{array}{l}\text { Li et al., } \\
\begin{array}{l}2010 \\
\eta(\%)\end{array}\end{array}$} & \multicolumn{2}{|c|}{ This study } \\
\hline & Smelter 1 & Smelter 2 & Smelter 3 & Smelter 4 & Smelter 5 & Smelter 6 & & & $\begin{array}{r}\text { Geometric } \\
\text { mean } \eta(\%)\end{array}$ & $\begin{array}{r}\text { Standard } \\
\text { deviation }\end{array}$ \\
\hline DC & 20.0 & 13.9 & 13.8 & - & 2.4 & - & - & - & 12.5 & 7.3 \\
\hline FGS & 66.6 & - & - & - & - & - & 17.4 & - & 42.0 & 34.8 \\
\hline ESD & 32.2 & - & - & - & - & - & 30.3 & - & 31.3 & 1.3 \\
\hline FGS+ESD & 88.2 & 99.0 & 99.3 & 80.5 & 76.2 & 97.5 & & & 90.1 & 10.1 \\
\hline RT & - & - & - & - & - & - & 87.5 & 91.4 & 89.5 & 2.8 \\
\hline DCDA & 99.2 & 80.0 & 30.4 & 90.9 & & 28.0 & 97.4 & - & 71.0 & 33.1 \\
\hline SCSA & - & - & - & - & 52.3 & - & - & - & 52.3 & - \\
\hline
\end{tabular}

most processes, dust collectors are widely installed for dehydration, overflow, extraction and refining/reclaiming flue gas. In several large smelters with advanced smelting processes, flue gas desulfurization (FGD) devices are installed. No APCDs are installed for the flue gas from the out-ofdate processes such as AZSP, RZSP and EF/RF. Therefore mercury removal efficiencies for other flue gas depend on the APCD applied. The mercury removal efficiencies of dust collector and FGD were $12.5 \%$ and $34.7 \%$, respectively (Table S6).

Atmospheric mercury emissions from $i$ province is calculated by

$E_{i}=\sum_{j} E_{i j}$

Atmospheric mercury emissions from $j$ process is calculated by

$E_{j}=\sum_{i} E_{i j}=\mathrm{EF}_{j} \times M_{j}=\mathrm{EF}_{j} \times \sum_{i} C_{\mathrm{com}, i j} \times \alpha_{j} \times \varphi_{j}$.

Thus, the average emission factor for $j$ process is

$$
\begin{aligned}
& \mathrm{EF}_{j}=\frac{1}{\sum_{i} C_{\mathrm{com}, i j} \times \alpha_{j} \times \varphi_{j}} \\
& \times\left[\sum_{i} \sum_{1} Q_{i j}\left(1-\gamma_{\mathrm{d}, j}\right) \gamma_{\mathrm{s}, j}\left(1-\xi_{\mathrm{of}, j}\right) \theta_{\mathrm{l}, i j}\left(1-\eta_{\mathrm{l}}\right)\right. \\
& +\sum_{i} Q_{i j} \gamma_{\mathrm{d}, j}\left(1-\eta_{\mathrm{o}, j}\right)+\sum_{i} Q_{i j}\left(1-\gamma_{\mathrm{d}, j}\right) \gamma_{\mathrm{s}, j} \xi_{\mathrm{of}, j}\left(1-\eta_{\mathrm{o}, j}\right) \\
& +\sum_{i} Q_{i j}\left(1-\gamma_{\mathrm{d}, j}\right)\left(1-\gamma_{\mathrm{s}, j}-\xi_{\mathrm{ss}, j}\right) \gamma_{\mathrm{e}, j}\left(1-\eta_{\mathrm{o}, j}\right)+ \\
& \sum_{i} Q_{i j}\left(1-\gamma_{\mathrm{d}, j}\right)\left(1-\gamma_{\mathrm{s}, j}-\xi_{\mathrm{ss}, j}\right)\left(1-\gamma_{\mathrm{e}, j}-\xi_{\mathrm{se}, j}\right) \\
& \left.\gamma_{\mathrm{r}, j}\left(1-\eta_{\mathrm{o}, j}\right)\right]
\end{aligned}
$$

where $\alpha$ is metal concentration and the values for zinc, lead and copper concentrates were 50.5, 62.85 and $21.7 \%$, respectively (Table S6) (CNMIA, 2011). $\varphi$ is metal recovery rate of smelting process. For most zinc smelting process, the metal recovery rate was $95.5 \%$ while for EP it was $94 \%$. For the lead and copper smelting processes, the metal recovery rate was $96.8 \%$ and $97.8 \%$, respectively (Table S6).

\section{Results and discussion}

\subsection{Regional atmospheric mercury emissions from primary smelters in 2010}

In 2010, total mercury input into China's primary nonferrous metal smelters with the consumption of ore concentrates in 2010 was $543 \mathrm{t}$, of which $74.8 \%, 19.5 \%$ and $5.7 \%$ was input into zinc, lead and copper smelters, respectively. However, mercury emitted into the atmosphere was about $72.5 \mathrm{t}$ from China's primary nonferrous metal smelters. Emissions from primary zinc, lead and copper smelters were 39.4, 30.6 and $2.5 \mathrm{t}$, respectively. The largest mercury emitter was the Gansu province, followed by Henan, Yunnan, Hunan, Inner Mongolia and Shaanxi provinces. Summation of the emissions from these six provinces accounted for $87.9 \%$ of the national emissions (Fig. 3).

China's zinc smelters emitted $39.4 \mathrm{t}$ of mercury into atmosphere in 2010. Gansu, Yunnan, Shaanxi and Henan provinces were the top four emitters. For zinc smelters, summation of mercury emissions from these four provinces accounted for $80.5 \%$ of national amount. The high mercury content of the zinc concentrate consumed was the main reason for the elevated mercury emissions in Gansu and Shaanxi province. For example, the mercury concentration in the concentrates consumed by zinc smelters in the Gansu province was as high as $403.4 \mathrm{~g} \mathrm{t}^{-1}$, which is about 10 times higher than the national average. Thus, the total mercury input into zinc smelters reached $181 \mathrm{t}$ in the Gansu province. If the national average was used, this value would be only $18 \mathrm{t}$. High mercury emissions in Yunnan and Henan are caused by the low application percentage of acid plants, which is only $79.3 \%$ and $48.5 \%$, respectively.

Atmospheric mercury emission from lead smelters was about 30.6t. Mercury emissions from China's lead smelters came mainly from Henan, Hunan, Yunnan and Inner Mongolia. The emissions of these four provinces accounted for $89.6 \%$ of total emissions from lead smelters. Huge consumption of concentrates, more than $60 \%$ of national consumption, was the most important factor for the high mercury emissions from lead smelters in Hunan and Henan. High 

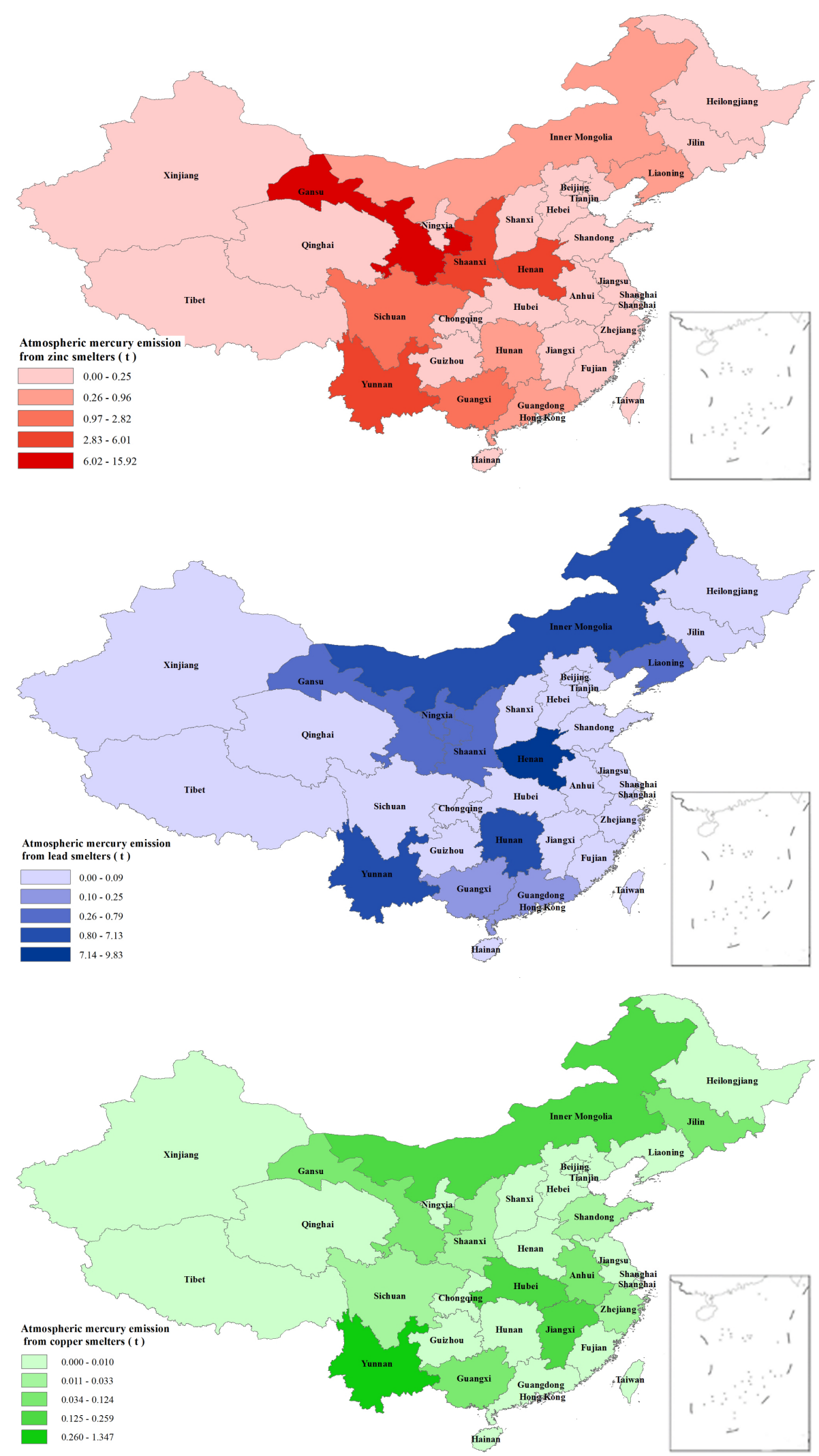

Fig. 3. Atmospheric mercury emissions from zinc, lead and copper smelters by province, 2010. 
mercury concentration in the concentrates consumed in Inner Mongolia contributed to its high emissions while low mercury removal efficiency led to the elevated emissions in Yunnan's lead smelters.

Copper smelters emitted $2.5 \mathrm{t}$ of mercury in 2010, and nearly half was emitted in the Yunnan province. High mercury content of copper concentrates consumed in local smelters was the main reason for the large mercury emissions in this province. Mercury content in the ore concentrates consumed by smelters in the Yunnan province was $8.7 \mathrm{gt}^{-1}$, about four times of the national average $\left(2.3 \mathrm{~g} \mathrm{t}^{-1}\right)$.

The mercury speciation profile was assumed to be $80 \%$ $\mathrm{Hg}^{0}, 15 \% \mathrm{Hg}^{2+}$ and $5 \% \mathrm{Hg}^{\mathrm{p}}$ for nonferrous metal smelting in previous estimate (Pacyna and Pacyna, 2002). The field experiments in Chinese nonferrous smelters provided a very different speciation profile (Wang et al., 2010; Zhang et al., 2012). In this study, the median of the results from field experiments was used to estimate mercury speciation emissions. For zinc smelters, the percentage of $\mathrm{Hg}^{2+}, \mathrm{Hg}^{0}$ and $\mathrm{Hg}^{\mathrm{P}}$ in emitted flue gas emitted to the atmosphere was $65 \%, 30 \%$ and $5 \%$, respectively. The $\mathrm{Hg}^{2+}, \mathrm{Hg}^{0}$ and $\mathrm{Hg}^{\mathrm{p}}$ emissions from zinc smelters were 25.6, 11.8 and $1.97 \mathrm{t}$, respectively. Using the same speciation profile, the $\mathrm{Hg}^{2+}, \mathrm{Hg}^{0}$ and $\mathrm{Hg}^{\mathrm{p}}$ emissions from lead smelters were 11.5, 17.6 and $1.53 \mathrm{t}$, respectively, and those for copper smelters were 1.19 , 1.16 and $0.12 \mathrm{t}$, respectively.

\subsection{Atmospheric mercury emissions from various smelting processes in 2010}

In 2010, China's production of zinc, lead and copper from primary smelters reached 5033, 2794 and $2921 \mathrm{kt}$, respectively. For primary zinc smelters, about $2.5 \%$ of refined zinc is produced by hydrometallurgical process. The rest was produced by EP, ISP, RZSP, EZF and others, accounting for $78.7 \%, 7.1 \%, 7.9 \%, 1.3 \%$ and $2.5 \%$ of total zinc production, respectively. For primary lead smelters, the percentages of lead produced by RPSP, ISP, SMP and SPP were $47.3 \%$, $5.1 \%, 20.2 \%$ and $27.4 \%$, respectively. Refined copper produced by FFSP, RPSP, IFSP, RLEP and EF/RF, accounted for $34.2 \%, 52.4 \%, 9.8 \%, 0.2 \%$ and $3.4 \%$, respectively.

For zinc smelters, most of mercury is emitted from smelters with EP. Mercury emissions from RZSP, EZF, ISP and AZSP were $6.3 \%, 2.4 \%, 5.4 \%$ and $14.4 \%$, respectively. For lead and copper smelters, more than half of the mercury was emitted from smelters with out-of-date technologies (Fig. 4). The average mercury removal efficiency of air pollution control devices in the zinc, lead and copper smelters was $90.5 \pm 52.5 \%, 71.2 \pm 63.7 \%$ and $91.8 \pm 40.7 \%$. The mercury emissions can be further reduced by improving the mercury removal efficiencies of current APCDs or by installing mercury reclaiming tower.
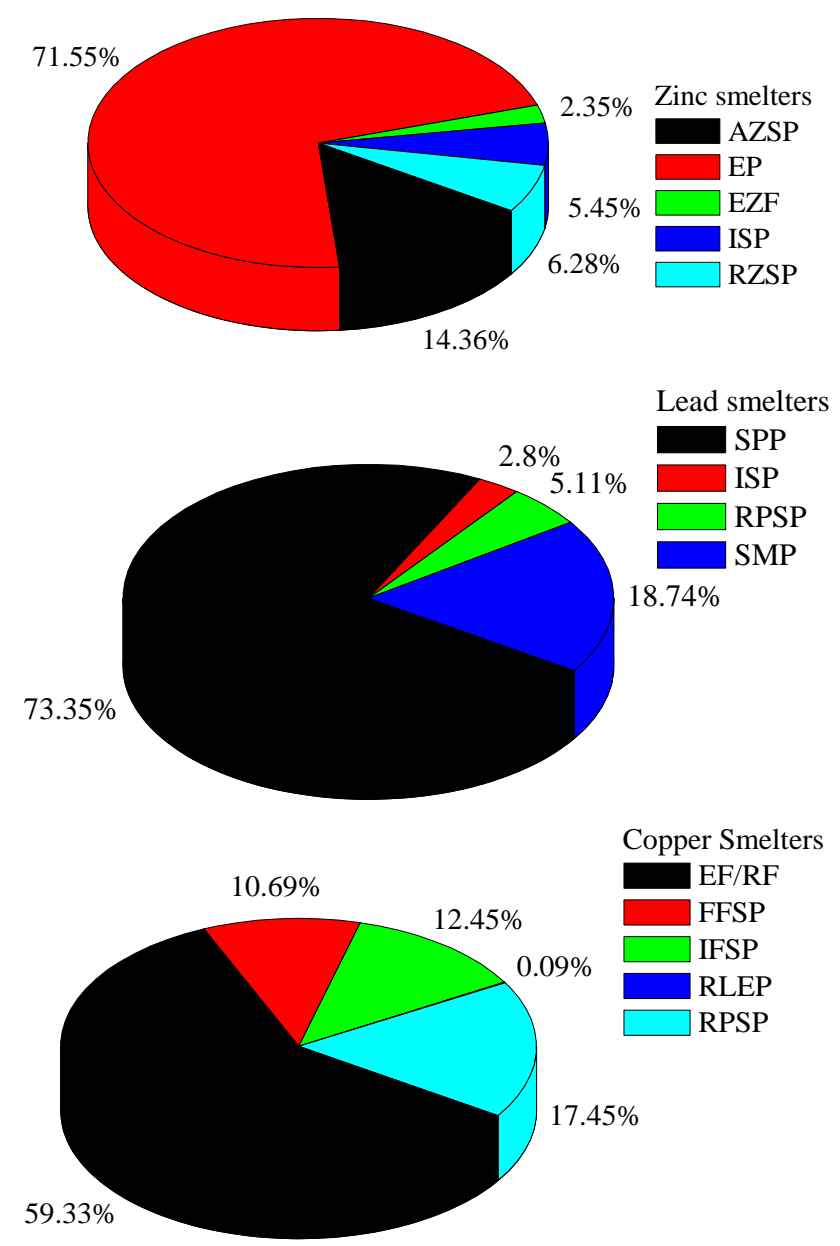

Fig. 4. Atmospheric mercury emissions from zinc, lead and copper smelters by process, 2010 .

\subsection{Uncertainty analysis}

The uncertainty of this inventory was estimated by combining the coefficients of variation $(\mathrm{CV}$, or the standard deviation divided by the mean) of the contributing factors according to the detailed methodology for uncertainty analysis described in Streets et al. (2003). The relative $95 \%$ confidence intervals for emissions are calculated as $1.96 \times \mathrm{CV}$. Thus, atmospheric mercury emission from zinc, lead and copper smelters was $39.4 \pm 31.5,30.6 \pm 29.1$, and $2.5 \pm 1.1 \mathrm{t}$ in $95 \%$ relative confidence and the uncertainty is $\pm 80 \%, \pm 95 \%$ and $\pm 45 \%$, respectively. In previous studies, the uncertainty for these three sources reached $100 \%, 200 \%$ and $100 \%$, respectively. The improvement in this study was contributed by better knowledge on the mercury content of ore concentrates and mercury removal efficiency of APCDs. However, more field experiments are still important to better understand the mercury fate in smelters. Besides, high uncertainties exist for the emissions from small-scale smelters. 


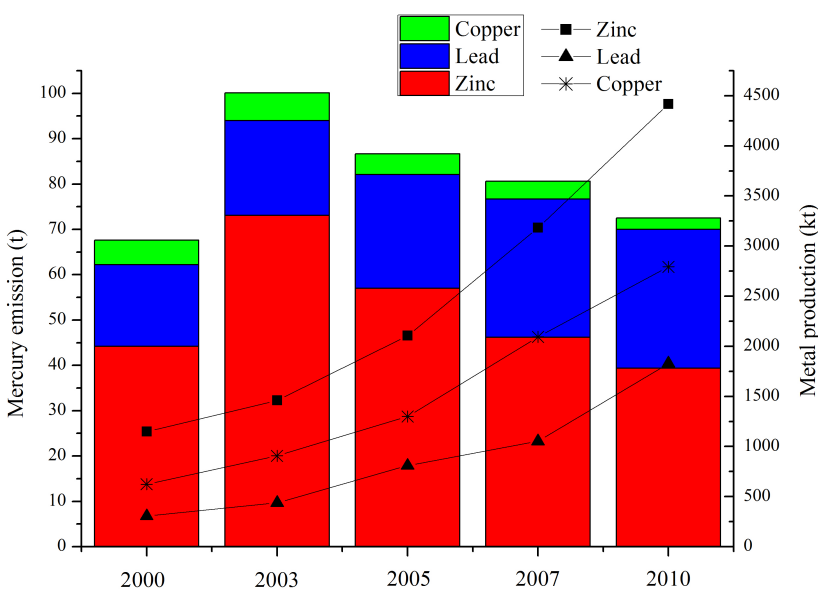

Fig. 5. Historic changes of atmospheric mercury emissions and metal production from nonferrous metal smelters in China, 20002010.

\subsection{Historical changes of mercury emissions from primary nonferrous metal smelters}

According to our estimation, atmospheric mercury emissions from nonferrous metal smelters in 2000, 2003, 2005, 2007 and 2010 were $67.6,100.1,86.7,80.6$, and $72.5 \mathrm{t}$, respectively. At the same time, the refined metal production from primary smelters increased from $3909 \mathrm{kt}$ to $4958,6460,8190$ and $10749 \mathrm{kt}$, respectively (see Fig. 5). The increased application percentage of acid plants was the main reason for the atmospheric mercury abatement in the past decade. Broadly speaking, the suitability of flue gas for making acid depends on its $\mathrm{SO}_{2}$ concentration determined by the smelting process. Flue gas from a process such as IFSP or SMP has a $\mathrm{SO}_{2}$ concentration lower than $3.5 \%$ and cannot be used to produce sulfuric acid. In that case, other flue gas desulfurization technologies such as ammonia absorption are applied. Flue gas produced from pool smelting processes, such as RPSP, usually has a $\mathrm{SO}_{2}$ concentration higher than $3.5 \%$ and can be used to produce sulfuric acid.

Mercury emissions will be further reduced after 2010 because of "the 12th five year national plan for comprehensive prevention and control of heavy metal pollution". In this plan, China has set a target that, by 2015 , the mercury emissions in certain key areas will be reduced by $15 \%$ on the basis of the 2007 emission level while mercury emissions in other areas will be maintained at the emission level of 2007.

\subsection{Comparison with previous studies}

In previous mercury emission inventory studies, the emission factor method was used and the difference in mercury emissions was mainly caused by the uncertainty of the emission factors (Tables 4,5 ). In earlier estimates, the mercury emission factors for China's nonferrous metal smelters were regarded as the same as those for other countries (Nriagu and Pacyna, 1988; Pacyna, 1996). Pirrone et al. (1996) assumed the mercury emission factors for zinc and lead smelters in developing continents to be 25 and $3 \mathrm{~g} \mathrm{t}^{-1}$ metal produced, respectively. But there were no data for developing countries including China. Wu et al. (2006) and Wang et al. (2006) analyzed the mercury content in concentrates and estimated the mercury emission factor to be $13.8-156.4,43.6$ and $9.6 \mathrm{~g} \mathrm{t}^{-1}$ for zinc, lead and copper smelters, respectively. However, these values were proven to be overestimated since the synergic mercury removal effect of APCDs was not considered (Feng et al., 2004; Li et al., 2010; Wang et al., 2010; Zhang et al., 2012). Feng et al. (2009) summarized previous studies and pointed out that the average emission factors were 5.4 $155 \mathrm{~g} \mathrm{t}^{-1} \mathrm{Zn}, 43.6 \mathrm{~g} \mathrm{t}^{-1} \mathrm{~Pb}$, and $9.6 \mathrm{~g} \mathrm{t}^{-1} \mathrm{Cu}$, respectively. If these three emission factors were adopted for emission estimation as that in Pirrone et al. (2010), the atmospheric mercury emission from nonferrous metal smelters in 2010 will reach $558 \mathrm{t}$. This indicated that atmospheric mercury emissions in China in 2010 will be overestimated by $400 \mathrm{t}$.

Hylander and Herbert (2008) considered mercury removal efficiencies in their study, and total atmospheric mercury emission from China's zinc, lead and copper smelters reached $83 \mathrm{t}$ in 2005, which is similar to our estimation. However, such similar results are coincidental due to their lower estimated ore mercury concentrations but also lower application percentages for acid plants. The weighted national average of mercury content in zinc, lead and copper concentrates consumed by smelters reached 47.02, 16.81 and $2.82 \mathrm{~g} \mathrm{t}^{-1}$, respectively. However, global mercury concentration of 10 , 9 and $3.5 \mathrm{~g} \mathrm{t}^{-1}$ for zinc, lead and copper concentrates was used in the former study. Thus, if we assumed concentrate consumption was the same in these two studies, the mercury input into Chinese nonferrous metal smelters was estimated to be higher than Hylander and Herbert's (2008) estimation. However, the application percentage of acid plants in 2005 was about $76.3 \%, 43.7 \%$ and $70.5 \%$ for zinc, lead and copper smelters, which was also higher than their estimation. According to Eq. (6), atmospheric mercury emissions from nonferrous metal smelters increased with the rise of mercury input and the descent of application percentage of acid plants. This indicates that the lower estimation of mercury input in Hylander and Herbert's study was offset by their lower estimation of application percentage of acid plants.

\section{Conclusions}

In this paper, we have presented an updated estimate of mercury emissions from nonferrous metal smelters using a detailed technology-based methodology specifically for China. We estimate that the mercury emissions from zinc, lead and copper smelters in China increased by $48.1 \%$, from $67.6 \mathrm{t}$ in 2000 to $100.1 \mathrm{t}$ in 2003 . After 2003, the mercury emissions decreased $27.6 \%$, from $100.1 \mathrm{t}$ in 2003 to $72.5 \mathrm{t}$ in 
Table 4. Atmospheric mercury emission estimation from China's zinc, lead and copper smelters between 2000-2010.

\begin{tabular}{crrrrl}
\hline \multirow{2}{*}{ Estimation year } & \multicolumn{3}{c}{ Atmospheric mercury emissions (t) } & \multirow{2}{*}{ Reference } \\
\cline { 2 - 5 } & Zinc & Lead & Copper & Total & \\
\hline 2000 & 161.4 & 48.0 & 12.7 & 222.1 & Wu et al. (2006) \\
2000 & 44.23 & 17.99 & 5.40 & 67.63 & This study \\
2001 & 173.0 & 54.3 & 13.7 & 241.0 & Wu et al. (2006) \\
2002 & 178.5 & 57.8 & 14.8 & 251.1 & Wu et al. (2006) \\
2002 & 80.7 & - & - & - & Li et al. (2010) \\
2003 & 187.6 & 70.7 & 17.6 & 275.9 & Wu et al. (2006) \\
2003 & 84.6 & - & - & - & Li et al. (2010) \\
2003 & 73.08 & 20.88 & 6.11 & 100.08 & This study \\
2004 & 97.1 & - & - & - & Li et al. (2010) \\
2005 & 37.59 & 29.75 & 15.84 & 83.19 & Hylander and Herbert (2008) \\
2005 & 97.4 & - & - & - & Li et al. (2010) \\
2005 & 56.98 & 25.14 & 4.57 & 86.69 & This study \\
2006 & 104.2 & - & - & - & Li et al. (2010) \\
2006 & 107.7 & - & - & - & Yin et al. (2012) \\
2007 & - & - & - & 203 & Pirrone et al. (2010) \\
2007 & 46.17 & 30.53 & 3.93 & 80.63 & This study \\
2010 & 39.4 & 30.6 & 2.5 & 72.5 & This study \\
\hline
\end{tabular}

Table 5. Comparison of mercury emission factors for China's primary zinc, lead and copper smelters.

\begin{tabular}{|c|c|c|c|c|c|c|c|c|c|c|c|c|c|c|}
\hline \multirow[t]{2}{*}{ Metal } & \multirow{2}{*}{$\begin{array}{l}\text { Smelting } \\
\text { Process }\end{array}$} & \multicolumn{13}{|c|}{ Mercury emission factor $\left(\mathrm{g} \mathrm{t}^{-1}\right)$} \\
\hline & & $\mathrm{A}^{\mathrm{a}}$ & $\mathrm{B}^{\mathrm{a}}$ & $\mathrm{C}^{\mathrm{a}}$ & $\mathrm{D}^{\mathrm{a}}$ & $E^{a}$ & $\mathrm{~F}^{\mathrm{a}}$ & $\mathrm{G}^{\mathrm{a}}$ & $\mathrm{H}^{\mathrm{a}}$ & $\mathrm{I}^{\mathrm{a}}$ & $\mathrm{J}^{\mathrm{a}}$ & $\mathrm{K}^{\mathrm{a}}$ & $\mathrm{L}^{\mathrm{a}}$ & $\mathrm{M}^{\mathrm{a}}$ \\
\hline \multirow[t]{7}{*}{ Zinc } & $-\mathrm{b}$ & $8-45$ & 25 & 20 & & $13.8-156.4$ & $7.5-8$ & 16.61 & $5.7-155$ & 7 & & & & 7.82 \\
\hline & EP with MRT & & & & & & & & & & 5.7 & 0.5 & & 0.59 \\
\hline & EP without MRT & & & & & & & & & & 31 & & 0.57 & 9.75 \\
\hline & RZSP & & & & & & & & & & 34 & & & 6.16 \\
\hline & $\mathrm{EZF}$ & & & & & & & & & & & & & 13.80 \\
\hline & ISP & & & & & & & & & & 122 & & 2.98 & 6.02 \\
\hline & AZSP & & & & $79 / 155$ & & & & & & 75 & & & 45.75 \\
\hline \multirow[t]{5}{*}{ Lead } & $-\mathrm{b}$ & $2-4$ & 3 & 3 & & 43.6 & 3 & 14.91 & 43.6 & 3 & & & & 10.97 \\
\hline & RPSP & & & & & & & & & & & & 1.00 & 1.19 \\
\hline & SMP & & & & & & & & & & & & 0.49 & 10.16 \\
\hline & SPP & & & & & & & & & & & & & 29.35 \\
\hline & ISP & & & & & & & & & & & & & 6.07 \\
\hline \multirow[t]{6}{*}{ Copper } & $-b$ & & & 10 & & 9.6 & $5-6$ & 6.72 & 9.6 & 5 & & & & 0.85 \\
\hline & FFSP & & & & & & & & & & & & 0.23 & 7.91 \\
\hline & RPSP & & & & & & & & & & & & 0.09 & 0.28 \\
\hline & IFSP & & & & & & & & & & & & & 1.07 \\
\hline & $\mathrm{EF} / \mathrm{RF}$ & & & & & & & & & & & & & 14.96 \\
\hline & RLEP & & & & & & & & & & & & & 0.38 \\
\hline
\end{tabular}

a (A) Nriagu et al. (1988); (B) Pirrone et al. (1996); (C) Pacyna et al. (2002); (D) Feng et al. (2004); (E) Streets et al. (2005); Wu et al. (2006); (F) Pacyna et al. (2006); (G) Hylander and Herbert (2008); (H) Pacyna et al. (2010); (I) Feng et al. (2009); (J) Li et al. (2010); (K) Wang et al. (2010); (L) Zhang et al. (2012); (M) This study.

b Not specific value for each process.

2010 although the production of zinc, lead and copper increased $116.7 \%$ in the same period. The mercury reduction is mainly due to the improvement of the smelting process and the increase of the application percentage of acid plants, from $60.9 \%, 30.7 \%$ and $61.0 \%$ in 2003 to $87.8 \%, 65.5 \%$ and $95.6 \%$ in 2010 for zinc, lead and copper smelters, respectively.

In 2010, atmospheric mercury emissions from zinc, lead and copper smelters were $39.4 \pm 31.5,30.6 \pm 29.1$, and $2.5 \pm 1.1 \mathrm{t}$ at relative $95 \%$ confidence and the uncertainty is $\pm 80 \%, \pm 95 \%$ and $\pm 45 \%$, respectively. $\mathrm{Hg}^{2+}, \mathrm{Hg}^{0}$ and $\mathrm{Hg}^{\mathrm{P}}$ 
emitted from zinc smelters were 25.6, 11.8 and $1.97 \mathrm{t}$, respectively. $\mathrm{Hg}^{2+}, \mathrm{Hg}^{0}$ and $\mathrm{Hg}^{\mathrm{p}}$ emissions were $11.64,17.74$ and $1.53 \mathrm{t}$ for lead smelters, respectively, while they were 1.19 , 1.16 and $0.12 \mathrm{t}$ for copper smelters, respectively. The average mercury removal efficiency of air pollution control devices in zinc, lead and copper smelters was $90.5 \pm 52.5 \%$, $71.2 \pm 63.7 \%$ and $91.8 \pm 40.7 \%$, respectively.

With better understanding of mercury fate in nonferrous metal smelters, atmospheric mercury emission estimates based on smelting processes and mercury abatement devices lower the estimation uncertainty. However, mercury removal efficiency estimates from current studies cover a broad range and the mercury removal mechanism of APCDs is still unclear.

\section{Supplementary material related to this article is available online at: http://www.atmos-chem-phys.net/12/ 11153/2012/acp-12-11153-2012-supplement.pdf.}

Acknowledgements. This work was financially supported by the Natural Science Foundation of China (No. 20937 002), MEP's Special Funds for Research on Public Welfares (201209015), and Government of Norway.

Edited by: R. Cohen

\section{References}

CNMIA (Chinese Nonferrous Metal Industry Association): The yearbook of nonferrous metals industry of China (2011), Chinese nonferrous metal industry association publications, Beijing, China, 2011.

Feng, X. B., Li, G. H., and Qiu, G. L.: A preliminary study on mercury contamination to the environment from artisanal zinc smelting using indigenous methods in Hezhang county, Guizhou, China - Part 1: Mercury emission from zinc smelting and its influences on the surface waters, Atmos. Environ., 38, 6223-6230, 2004.

Feng, X., Streets, D., Hao, J., Wu, Y., and Li, G.: Mercury emissions from industrial sources in China, Springer, New York, USA, chap. 3, 67-79, 2009.

Fukuda, N., Takaoka, M., Doumoto, S., Oshita, K., Morisawa, S., and Mizuno, T.: Mercury emission and behavior in primary ferrous metal production, Atmos. Environ., 45, 3685-3691, 2011.

Hylander, L. D. and Herbert, R. B.: Global emission and production of mercury during the pyrometallurgical extraction of nonferrous sulfide ores, Environ. Sci. Technol., 42, 5971-5977, 2008.

Kocman, D. and Horvat, M.: Non-point source mercury emission from the Idrija $\mathrm{Hg}$-mine province: Gis mercury emission model, J. Environ. Manage., 92, 2038-2046, 2011.

Li, G. H., Feng, X. B., Li, Z. G., Qiu, G. L., Shang, L. H., Liang, P., Wang, D. Y., and Yang, Y. K.: Mercury emission to atmosphere from primary Zn production in China, Sci. Total Environ., 408, 4607-4612, 2010.
Li, P., Feng, X. B., Qiu, G. L., Shang, L. H., and Li, Z. G.: Mercury pollution in Asia: A review of the contaminated sites, J. Hazard. Mater., 168, 591-601, 2009.

Lin, C.-J., Pan, L., Streets, D. G., Shetty, S. K., Jang, C., Feng, X., Chu, H.-W., and Ho, T. C.: Estimating mercury emission outflow from East Asia using CMAQ-Hg, Atmos. Chem. Phys., 10, 1853-1864, doi:10.5194/acp-10-1853-2010, 2010.

Nriagu, J. O. and Pacyna, J. M.: Quantitative assessment of worldwide contamination of air, water and soils by trace-metals, Nature, 333, 134-139, 1988.

Pacyna, J. M.: Emission inventories of atmospheric mercury from anthropogenic sources, in: Global and regional mercury cycles: sources, fluxes and mass balances, Nato science partnership subseries 2, edited by: Baeyens, W., Ebinghaus, R., and Vasiliev, O., Reidel publishing company, Dordrecht, The Netherlands, 123136, 1996.

Pacyna, E. G. and Pacyna, J. M.: Global emission of mercury from anthropogenic sources in 1995, Water Air Soil Pollut., 137, 149165, 2002.

Pacyna, E. G., Pacyna, J. M., Steenhuisen, F., and Wilson, S.: Global anthropogenic mercury emission inventory for 2000, Atmos. Environ., 40, 4048-4063, 2006.

Pacyna, E. G., Pacyna, J. M., Sundseth, K., Munthe, J., Kindbom, K., and Wilson, S.: Global emission of mercury to the atmosphere from anthropogenic sources in 2005 and projections to 2020, Atmos. Environ., 44, 2487-2499, 2010.

Pirrone, N., Keeler, G. J., and Nriagu, J. O.: Regional differences in worldwide emissions of mercury to the atmosphere, Atmos. Environ., 30, 2981-2987, 1996.

Pirrone, N., Cinnirella, S., Feng, X., Finkelman, R. B., Friedli, H. R., Leaner, J., Mason, R., Mukherjee, A. B., Stracher, G. B., Streets, D. G., and Telmer, K.: Global mercury emissions to the atmosphere from anthropogenic and natural sources, Atmos. Chem. Phys., 10, 5951-5964, doi:10.5194/acp-10-59512010, 2010.

Streets, D. G., Bond, T. C., Carmichael, G. R., Feamdes, S. D., Fu, Q., He, D., Klimont, Z., Nelson, S. M., Tsai, N. Y., Wang, M. Q., Woo, J.-H., and Yarber, K. F.: An inventory of gaseous and primary aerosol emissions in Asia in the year 2000, J. Geophys. Res., 108, 8809-8831, 2003.

Streets, D. G., Hao, J. M., Wu, Y., Jiang, J. K., Chan, M., Tian, H. Z., and Feng, X. B.: Anthropogenic mercury emissions in China, Atmos. Environ., 39, 7789-7806, 2005.

Strode, S., Jaegle, L., and Selin, N. E.: Impact of mercury emissions from historic gold and silver mining: global modeling, Atmos. Environ., 43, 2012-2017, 2009.

The State Council of the People's Republic of China: Notice on further strengthening the work of eliminating out-of-date production capacity, online available at: http://www.gov.cn/zwgk/2010-04/ 06/content_1573880.htm, 2010.

Tian, H. Z., Wang, Y., Xue, Z. G., Cheng, K., Qu, Y. P., Chai, F. H., and Hao, J. M.: Trend and characteristics of atmospheric emissions of $\mathrm{Hg}$, As, and Se from coal combustion in China, 19802007, Atmos. Chem. Phys., 10, 11905-11919, doi:10.5194/acp10-11905-2010, 2010.

Wang, S. X., Liu, M., Jiang, J. K., Hao, J. M., Wu, Y., and Streets, D. G.: Estimate the mercury emissions from non-coal sources in china, Chinese Environ. Sci., 27, 2401-2406, 2006. 
Wang, S. X., Song, J. X., Li, G. H., Wu, Y., Zhang, L., Wan, Q., Streets, D. G., Chin, C. K., and Hao, J. M.: Estimating mercury emissions from a Zinc smelter in relation to China's mercury control polices, Environ. Pollut., 158, 3347-3353, 2010.

Wu, C. L., Cao, Y., Dong, Z. B., Cheng, C. M., Li, H. X., and Pan, W. P.: Evaluation of mercury speciation and removal through air pollution control devices of a 190 MW boiler, J. Environ. Sci., 22, 277-282, 2010.

Wu, Y., Wang, S. X., Streets, D. G., Hao, J. M., Chan, M., and Jiang, J. K.: Trends in anthropogenic mercury emissions in China from 1995 to 2003, Environ. Sci. Technol., 40, 5312-5318, 2006.
Yin, R. S., Feng, X. B., Li, Z. G., Zhang, Q., Bi, X. W., Li, G. H., Liu, J. L., Zhu, J. J., and Wang, J. X.: Metallogeny and environmental impact of $\mathrm{Hg}$ in $\mathrm{Zn}$ deposits in China, Appl. Geochem., 27, 151-160, 2012.

Zhang, L., Wang, S. X., Wu, Q. R., Meng, Y., Yang, H., Wang, F. Y., and Hao, J. M.: Were mercury emission factors for Chinese non-ferrous metal smelters overestimated? Evidence from onsite measurements in six smelters, Environ. Pollut., 171C, 109-117, 2012. 